\title{
The Birds of Prey
}

For Boy Scouts

\section{By GEORGE E. HIX}

Scoutmaster Troop 105, Brooklyn, N. Y.

Associate American Ornithologists' Union;

Resident Member Linnaean Society of New York

\section{Price, 25 Cents}

Copies may be ordered from the author at 337 Seventy-second Street, Brooklyn, N. Y. 


\section{SPECIAL COLIECTIONS \\ DOUGLAS \\ LIBRARY \\ LORNE \\ 판 FIERCE}

Presented by

The Family of

HAVETOCK ROBB

from his library

1985

Queen's University at Kingston 


\section{The Birds of Prey}

\section{For Boy Scouts}

By GEORGE E. HIX

Scoutmaster Troop 105, Brooklyn, N.Y.

Associate American Ornithologists' Union; Resident Member

Linnaean Socicty of New York

"Produce a list from personal reading, of ten birds of prey particularly useful in the destruction of rodents." (Requirement No. 4 Merit Badge for Bird Study.)

Due to the inability of the average Boy Scout to obtain books with enough details as to the food and habits of the birds of prey, this requirement has always been troublesome. The small books which fit in the pocket obviously cannot contain extensive accounts of each species.

This pamphlet is written with the sole idea of giving to Scouts the benefit of the writer's experiences and the study and knowledge of the leading ornithologists in the United States and Canada.

The greater part of the knowledge of the food of birds of prey has been obtained by the examination of stomachs. Experts can tell what food has been eaten by remains in the stomach. In the case of Owls the pellets which are disgorged are the remains of the creatures which have been eaten. These pellets upon examination will be found to contain the skin and bones of the victims. Owls swallow their prey whole when it is not too large, and disgorge the undigested parts.

Chiefly through ignorance, farmers and sportsmen are against all Hawks which they class as "vermin." Sportsmen claim that Hawks and Owls are responsible for the depletion of the stock of game birds. They never stop to consider that from ages back birds of prey and game birds have existed without the former wiping out the latter. The main reason for the scarcity of game birds at the present time is the gunner and his gun. When hundreds 
of thousands of hunters roam the fields each year, it is easy to see the toll which is taken from among our wild-life. In a certain part of New Jersey, the Bob White or Quail was once abundant It is now very many years since I have either seen or heard one in that section. An old farmer whose place I visited many a time, when asked what had become of the Quail, answered "Oh we shot 'em all." Here is the answer.

It is the slow-flying Hawks which are accused of raiding the poultry yards, while the real culprits are the swift, slender species. The former from their habit of soaring in plain view are easily seen and are of course blamed. The latter fly low, pick up their victims and are out of sight before it is realized what happened. Among the Owls those species which fly during the day or perch in exposed places are the victims of the thoughtless gunner or farmer. Fortunately most of the beneficial Owls spend the daytime hidden in evergreen or densely foliaged trees. The casual passerby would not suspect that an Owl was near if he did not know the signs of the bird's presence.

The species described here are those which are more or less generally distributed over North America from the southern border of the United States northward. Some species which in the United States occur only in the southern parts of Arizona, Texas and New Mexico, and are not common there, are omitted. The Gyrfalcons of the north are also omitted as they very rarely come southward.

\section{THE VULTURES}

Vultures are large birds which feed chiefly upon carrion. The bill is stout, blunt, and hooked; the talons are dull and only slightly curved, and the feet are clumsily formed and not adapted to seizing and killing or holding prey. The head and neck are devoid of feathers. On the ground or perched vultures are as a rule ugly birds, but in the air they are marvels of grace as they sail along with scarcely a wing-beat.

Vultures build no nests but lay their eggs in rock cavities, caves, hollow trees or stumps, or on the ground. 


\section{California Vulture}

General description. Length, 4 to $4 \frac{1}{2} 2$ feet; spread of wings, 9 to 11 feet. Head and neck, bare, the skin yellow, or yellowishorange and red; plumage, sooty-blackish, some of the feathers with brown or grayish tips or edges; under wing-coverts pure white.

The California Vulture is as large as the Condor of the Andes. It is in fact more often called the California Condor. It seldom, if ever, attacks living creatures depending upon those which have died to furnish it food.

The range of the California Condor is more restricted than that of any other bird of prey. The few left in the wild state live almost entirely in the coastal mountainous region of southern California and a part of Lower California. Even here it is becoming scarcer. Their feeding upon predatory animals which had been poisoned by cattle raisers, is thought to be the reason for their present rarity. At one time their range was more extensive.

\section{Turkey Vulture}

General description. Length, $2 \frac{1}{2}$ feet; spread of wings, 6 feet. Head and neck bare, red in adult, dark-colored in young; plumage dark, very nearly black.

Seen at close range the Turkey Vulture is one of the ugliest birds. On the wing it is a thing of beauty and grace, as it sails along with hardly a wing-beat, rocking in the air.

The food of the Turkey Vulture is mainly carrion, but it will eat snakes, toads and other creatures if forced to do so. As it is not adapted to seizing living prey, when it does feed upon such, the creatures are probably near death anyhow. Its keen eyesight enables it to spy a carcass from a great distance. When one bird sees and alights to feed upon a carcass others soon join it, appearing to come from nowhere.

The Turkey Vulture is found generally from southern Lower California and northern Mexico north to southern British Columbia, Saskatchewan, western Manitoba, northern Minnesota, western Ontario, western and southern New York and New Jersey. I have found it a very common bird in Sussex County, New Jersey. 
It is also common around Princeton, N. J., and increases in abundance southward. I also found it very common in the mountainous regions north of San Francisco. In the immediate vicinity of New York City it is rare. It does not occur regularly as far north along the Atlantic Coast as it does inland and west. It is casual as far north as Massachusetts.

\section{Black Vulture}

General description. Length, 27 inches; spread of wings $41 / 2$ feet. The bare head and neck are black; entire plumage, blackish; under wing-coverts white.

The Black Vulture is a smaller and stumpier bird than the Turkey Vlulture. Its tail is shorter and the white under wingcoverts distinguish it from its larger relative. On the wing it flaps more.

In some of our southern cities Black Vultures roam the streets like domestic pigeons. They feed upon offal and refuse. Of course modern sanitation has done away with this to some extent. They are protected both by law and sentiment.

The Black Vulture ranges from western Texas, Kansas, Illinois, Indiana and Virginia, southern Maryland, south through the Southern States, Mexico and Central America. It is casual further north.

\section{THE KITES}

The Kites are birds of southern distribution and are known for their beauty and grace upon the wing.

\section{W/hite-Tailed Kite}

General description. Length, 17 inches. Upper parts, light bluish-ash; under parts and tail, white. Wings, pointed and about twice as long as the tail and when closed reaching nearly to the end of tail. Young birds are more or less streaked. The shoulders of adult birds are black, the young brown.

The white square tail and black shoulders of the White-tailed Kite are distinctive field marks. Its favorite haunts are along the 
borders of streams and marshes, where it frequently perches upon trees overlooking its hunting grounds.

The White-tailed Kite sometimes feeds upon birds as well as upon lizards, snakes and grasshoppers. It also frequently feeds upon small mammals, especially field mice.

The White-tailed Kite is found in California, Texas, Oklahoma and Florida.

\section{Swallow-Tailed Kite}

General description. Length, 24 inches. Head and under parts, white; upper parts, black. Wings long and reaching nearly to the tip of the deeply-forked tail; outer tail-feathers about 8 inches longer than the middle pair.

No other North American bird approaches the Swallow-tail in the grace and beauty of its flight; the Duck Hawk alone equals it in speed. Although I have never, seen this bird, I should imagine that it resembles a very large swallow.

The Swallow-tail feeds upon snakes, lizards, insects, frogs, and snails. It never touches birds or mammals.

The Swallow-tail breeds in the southeastern parts of the United States. It sometimes is found further north. During the late summer of 1928 one was seen in the Bronx section of New York City.

\section{Mississippi Kite}

General description. Length, 14 inches. Color, bluish-gray; tail black.

The Mississippi Kite is stronger and more robust than the others of this group. It also shows more spirit. It feeds upon lizards, small snakes, frogs, grasshoppers, and some beetles. Its food is eaten upon the wing.

The Mississippi Kite is found from northeastern Kansas, southern Illinois, southern Indiana, and South Carolina south to Texas and Florida. 


\section{Everglade Kite}

General description. Length, 18 inches. Color, dark bluishgray with some white at the base of the tail. Parts of the wings and tail incline more to black. The young are brownish-black above; below dull ochre, streaked with dusky.

The formation of the bill of the Everglade Kite enables it to extract from its shell the fresh-water snail upon which it feeds almost exclusively. This Kite is confined to the region of the Everglades in Florida where the snail is abundant. The empty shells of the snails may be found in heaped-up mounds where the Kites have dropped them after eating the meat.

\section{THE SHORT-WINGED HAWKS}

These Hawks have short rounded wings, and long tails. They vary in size from very small to large. They are all daring and swift, pouncing upon their prey like a streak. They feed mostly upon birds and are our more destructive Hawks. They do not perch out in the open but lurk along the edges of woods, and pounce out upon their unsuspecting victims.

In Europe this group is known as the "True Hawks."

\section{American Goshawk}

General description. Length; male, 22 inches; female, 24 inches. Adults: top and back of head black; rest of upper parts dark bluish-slate; a white stripe over the eye; under parts finely barred or streaked with black or slate. Young birds resemble the young of Cooper's Hawk except for size. The adult is a very striking bird with its gray upper parts and black cap.

This is the most destructive of our Hawks. It is the real "chicken hawk." It catches partridges, grouse, poultry, rabbits, squirrels, etc.

Goshawks have spent the winter in the Hemlock Grove of Bronx Park, New York City. They probably obtained most of their food from amongst the park squirrels and domestic pigeons. 
I have seen it in Brooklyn in the back yard of one of the oldtime houses feeding upon something which it evidently had caught near at hand.

The American Goshawk inhabits the northern wooded sections across the continent. Sometimes in winter it comes down to the prairie sections. When this species does come southward it usually comes in numbers. It does not hesitate to come near dwellings to prey upon domestic fowls. Two races are now recognized, the Eastern and the Western Goshawk.

\section{Sharp-Shinned Hawk}

General description. Length; male, 11 inches; female, 12 to 14 inches. Color: Adults are dark bluish-slate above; breast barred with dull reddish and white. Immature birds are brown above and streaked with brown beneath.

Small, swift and daring, the Sharp-shinned Hawk takes a heavy toll from small bird life. More than once I have been watching a Song Sparrow or other small bird, and have had a Sharpshinned Hawk swoop down and pick it up from almost under my nose. It happened more quickly than it can be told.

On account of its small size the Sharp-shinned Hawk does not molest the chicken-coop as its larger relatives the Cooper's Hawk and Goshawk do. Fortunately the Sharp-shinned Hawk is not abundant as a breeder. In the summer a single pair may be the only ones in quite an area. It is during migrations that most havoc is played amongst small birds.

The Sharp-shinned Hawk is found throughout most of North America. In the United States and Canada it breeds in the wooded sections.

\section{Cooper's Hawk}

General description. Length; male, 18 inches; female, 20 inches. Same proportions as the Sharp-shinned Hawk but larger and with tail rounded instead of square. Color similar to that of the Sharp-shinned Hawk at the same ages.

Cooper's Hawk is a larger edition of the Sharp-shinned, in fact 
a small male Cooper's Hawk is not very much larger than a large female Sharp-shin. The chief identification mark between the two species is the tail. In flight the tail of the Sharp-shinned Hawk appears to be square while that of Cooper's is rounded.

Cooper's Hawk is bold and fierce. It feeds upon birds and often catches young or feeble chickens. A healthy full grown fowl is probably too much for it. Where this species is common it is quite a menace to bird-life. It feeds upon mammals to a very small extent.

Cooper's Hawk breeds from southern British Columbia, central Ontario, Alberta, central Quebec and Prince Edward Island south to the southern border of the United States. It does not range as far north as does the Sharp-shin.

\section{THE BUZZARD HAWKS}

These are heavily built Hawks of medium or very large size. Round, broad wings; broad, full tail, and habits of soaring in the open are good field marks of this group. These are the true buzzards. On account of their heavy build they are not swift like the smaller Short-winged Hawks and Falcons.

The Buzzards are the most beneficial of our Hawks. Their food is mostly rodents and in the prairie regions they destroy countless numbers of prairie dogs, gophers, rabbits and similar mammals.

\section{Red-Tailed Hawk}

General description. Length; male, 22 inches; female, 24 inches. Upper parts dark brown mixed or mottled with gray and whitish; under parts white, more or less washed with buffy and streaked with dark brown or blackish on sides of breast and abdomen; tail, bright rust-red or rufous above, usually with a black bar near the end, top whitish. Immature birds lack the red tail and are much more streaked and blotched underneath.

The Red-tailed Hawk in its various forms is probably our best known Hawk and the one to which the misnomer "Chicken Hawk" is most often applied. 
In summer the Red-tail is a denizen of the woodland, building its nest in the top of a tall tree. In winter it inhabits more open country. In the vicinity of New York City it frequents marshlands which are bordered with woods. It is a common bird in the Hackensack marshes of New Jersey, where it finds rats abundant. It and the Marsh Hawk do more than their share in keeping these pests in check. There are numerous dumps in these marshes and the common house rat soon overruns them.

In the central part of the United States and the south-central part of Canada the Red-tail feeds upon snakes, frogs, squirrels, gophers, prairie dogs and other similar creatures. Elsewhere it is partial to meadow mice, snakes, etc. The fowls that it captures are old or diseased. It is better for the stock that these be eliminated.

It is a majestic sight to see a pair of Red-tailed Hawks circling and soaring overhead. When they turn at a tilt it is a good chance to observe the red tail if the birds are adult. The Red-tailed Hawk probably soars more than do the other Buzzards.

There are various forms of the Red-tailed Hawk but they are too confusing for treatment here. The Western Red-tailed Hawk is much darker than the typical form. This variety occurs in western North America from Alaska and Mackenzie southward to Cape San Lucas and Guatemala. The Alaska Red-tail is a larger dark-colored variety. There are other forms which may be only color phases.

\section{Red-Shouldered Hawk}

General description. Length; male, 20 inches; female, 22 inches. Color above, reddish-brown; below, lighter reddish-brown, barred and streaked; there are white spots on the wings; the shoulders are rufous or chestnut; tail, brownish-black with six sharply defined white stripes, the last at the tip and the first two concealed by the coverts. Young: Above, plain dark brown without orange-brown or rusty markings; some rusty in the wings, head, neck, and underparts white, heavily streaked with arrow- 
shaped marks of dark brown; tail, brown, crossed by a number of lighter and darker bars.

The Red-shouldered Hawk is nearly as common as the Redtailed but is less often seen as it is more a denizen of the woods. It is not as heavy a bird as the Red-tail. In the vicinity of New York City this Hawk is more common than the Red-tail in summer. In winter it is the reverse.

Red-shouldered Hawks quite frequently visit Central Park, New York City. Next to the Broad-winged it is the large Hawk most often seen in the park or was up to ten or so years ago.

Red-shouldered Hawks are very valuable to the farmer. They are more omnivorous than most of our birds of prey, feeding upon mice, birds, frogs, snakes, grasshoppers, snails, etc. More than once I have seen a Red-shouldered Hawk with a large snake in its talons.

The adult bird may be easily recognized by the rusty underparts and the white bands on the tail. Young birds are very confusing to the novice and often to the expert when too far away to note the markings.

The Red-shouldered Hawk is found over most of eastern North America up to the spruce forests. In the southern Atlantic and Gulf States, from South Carolina through Texas into Mexico, is a smaller form known as the Florida Red-shouldered Hawk.

From the Rocky Mountains to the Pacific, in California south into Mexico, there is a bird known as the Red-bellied Hawk. It is considerably brighter and richer in color, and is stated to have different habits and bearing. It is described as being Owl-like in flight and may be a distinct species from the eastern bird.

\section{Broad-Winged Hawk}

General description. Length; male, 14 inches; female, 18 inches. Upper parts brown, lower parts white, barred or streaked; tail crossed with three grayish-white bars.

The Broad-winged Hawk is a bird of the woods. It often 
remains motionless for hours in the top of a tall tree. While apparently asleep, it really is on the watch for prey.

This is a harmless and beneficial species. In Central Park, New York City, during migrations I have often seen a Broadwinged Hawk perched in a tree with various small birds around. He did not go after them and they paid no attention to him.

The Broad-winged Hawk is found over most of North America east of the Mississippi. In winter it reaches Venezuela and Peru. This Hawk is often seen in large numbers during migrations. It usually flies high at that time.

\section{Swainson's Hawk}

General description. Length; male, 20 inches; female, 22 inches. There is great variation in color in this species. In the normal plumage the bird is grayish-brown above, usually somewhat regularly barred on the tail; throat white; the under parts whitish, creamy or buff, usually barred and spotted with brown; there is a broad dark band across the chest. In the dark phase the entire plumage is near-black. Between the two plumages there is considerable intergradation.

Swainson's Hawk is a bird of the open. On the sage plains and prairies of the Western States and Canada it is abundant. I made the acquaintance of this Hawk in eastern Alberta and crossing Saskatchewan on the Canadian National Railroad. These birds soar gracefully over the prairies and when prey is found pounce upon it suddenly. Several were observed from the train doing this.

Swainson's Hawk is probably the most beneficial of all the species found in the United States and Canada. It keeps gophers and mice in check and destroys countless grasshoppers. It is of gentle disposition and lives in harmony with other birds, in fact it often shares the same nest with them, other birds making use of the same structure.

Swainson's Hawk is found in western North America north to the tree limit and east to the Mississippi. It also reaches South America in the winter. 


\section{THE ROUGH-LEGGED HAWKS}

These are large heavily built Buzzard Hawks with legs heavily feathered. This latter feature gives them their name.

\section{American Rough-Legged Hawk}

General description. Length; male, 20 inches; female, 22 inches. Upper parts, grayish-brown; under parts, white or buffy, streaked with blackish, forming a band across the abdomen; tail whitish at the base. There is a melanistic phase in which the whole plumage is sooty-black, except base of tail and portions of the wing-feathers which are white.

The Rough-legged Hawk breeds in Alaska and Canada and is only a winter visitor to the United States. It frequents open meadows and mashes, much the same type of country as does the Marsh Hawk. It flies to and fro like the Marsh Hawk but lacks the grace of the latter. To me it appears to be rather clumsy. It sometimes hovers like the Sparrow Hawk. In the Hackensack meadows where I know it best, it finds a bountiful food supply in the rats which infest the dumps. It is one of the most beneficial of the Hawks.

The Rough-legged Hawk is often seen flying about at dusk which is very unusual for Hawks.

\section{Ferruginous Rough-Leg}

General description. Top, back and sides of head streaked equally with blackish and white; rest of upper parts blackish and chestnut; tail silvery tinged with rufous and with white tip and base; under parts white; legs chestnut barred with black. There is also a dark phase, and there is great variation in the light phase.

This harmless large Hawk is a species of the prairie regions. It is very unsuspicious. I have seen a Ferruginous Rough-leg sitting upon a post while the fast trans-continental train in which I was travelling sped by, and remain sitting there after the train had passed.

Prairie dogs, gophers, and sinilar mammals form a large part 
of the food of the Ferruginous Rough-leg. It is well that he does feed upon these mammals as they are pests in certain localities. This Hawk deserves protection.

There is great variation in plumage as mentioned above. Some specimens are very light in color; there is the dark phase, and a lot of in-between plumages.

This Hawk breeds from southern Alberta, Manitoba to northeastern California, eastern Oregon, Utah, southern Arizona and New Mexico and Kansas, and winters from Montana to Lower California and northern Mexico. It is rare east of the Mississippi River.

\section{Harris's Hawk}

General description. Length; male, 20 inches; female, 23 inches. Adults: General plumage, blackish, varying in shade; a large patch on the wing and feathers of the leg, a deep rich chestnut; base of tail white. The young are more brownish and streaked, and the chestnut is duller; the white on the tail is less sharply defined.

This tame unsuspicious Hawk is found in southeastern California, southern Arizona, southern New Mexico and southern Texas, Louisiana and Mississippi. It is abundant in some parts of the last named state. Harris's Hawk is found in the sagebrush thickets of the deserts. Its food is chiefly wood-rats and chipmunks. It often feeds upon carrion.

\section{THE EAGLES}

The Eagles are the largest diurnal birds of prey. They are noted for their powers of flight and their strength. On account of their size they are able to prey upon quite large animals. There are only two species found in the United States, the Golden Eagle and the Bald Eagle. The former is a true Eagle and is noted for its boldness. The latter belongs to the group known as "Sea Eagles" and is more of a carrion feeder.

\section{Golden Eagle}

General description. Length, about 3 feet; spread of wings, 
7 to $71 / 2$ feet. Plumage, dark brown. Legs feathered to the toes. Adult birds show golden-brown tips to the feathers of back of head, nape and sides of neck. Young birds are larger than the adults and the base of the tail is mostly white.

The Golden Eagle is common in the west but rare in the east. Its large size and strength enable it to carry off fawns, sheep, etc. On this account it is in disfavor with the ranchers. It also feeds upon the various wild animals of the prairies.

The Golden Eagle is equally at home either upon the open plains or up among the mountain peaks. I have seen it in both places. It was quite a thrill to be eating dinner in an inn upon Mt. Tamalpais near San Francisco, and in looking out of a window to see two Golden Eagles soaring but a short distance away. The yellowish wash to the plumage was plainly seen.

The Golden Eagle does more hunting than the Bald Eagle. It catches rabbits, fawns, prairie dogs, turkeys, grouse and waterfowl. In the open prairie it keeps in check various animals that might become too numerous. Too near habitations, it will attack domestic animals and poultry.

The Golden Eagle is distributed generally over the northern part of the Northern Hemisphere. In America it extends across the continent and to the Arctic Ocean but is rare in the east.

\section{Bald Eagle}

General description. Length; male, 30 to 35 inches; female, 34 to 43 inches. Spread of wings, $61 / 2$ to $73 / 4$ feet. Entire head, neck, upper tail-coverts, and tail white; rest of plumage, dark brown. Immature birds are entirely dark variously mottled with lighter. First year birds are mainly black.

The Emblem of the United States, this magnificent bird never fails to thrill the nature lover. An adult with white head and tail is an inspiring sight as it soars or majestically flaps with powerful wing-beats.

The Bald Eagle is rather common along the lower Hudson 
River when there is plenty of ice. They float down stream upon cakes of ice and when river traffic is reached, fly up stream again. They feed upon fish and sometimes rob the Gulls of their catch. Only the adult birds appear to worry the Gulls. I have never seen Eagles molest the Ducks which are abundant in the river at this time.

Bald Eagles are also very common along the Potomac River during the duck-hunting season. Many Ducks are killed or wounded and not recovered by the gunners. The Eagles watch out for these and do not let them go to waste. During a trip by boat down the Potomac River as many as 40 or 50 Bald Eagles may be seen in one day.

In Alaska Bald Eagles are considered pests on account of their feeding upon salmon and bounties have been placed upon them. Most fish eaten by Eagles is that which has been cast upon the shore. The Bald Eagle is not a good fisherman. His attacking the Osprey and forcing him to drop his prey and then catching it before it strikes the water is a familiar story. He also eats small mammals.

The Bald Eagle is a member of the group known as "Sea Eagles." At one time young birds were thought to be a different species, as during the first year they are larger than the adult birds. Audubon, the great American ornithologist, called the young bird the "Washington Sea Eagle."

The Bald Eagle is found over practically the entire United States but is rare in the arid regions. It likes to be near water such as large rivers and lakes.

In northwestern Alaska, northwestern Mackenzie, and northern Ungava south to British Columbia and the Great Lakes occurs a larger bird known as the Northern Bald Eagle.

\section{THE HARRIERS}

The Harriers are long-winged, long-tailed Birds of Prey of light slender build. There is only one species in North America. 


\section{Marsh Hawk}

General description. Length, 19 inches. Adult male. Fore and upper parts ashy, abdomen white; female, brown above and brownish-white below. Immature similar to female, but darker. All have white rump.

Salt marsh, fresh marsh, prairie region or grain fields, in all these places the Marsh Hawk is equally at home. An adult male with its gray plumage resembles a Gull and makes a beautiful picture as it wings its way across the open spaces keeping a sharp lookout for rats and mice.

In the Hackensack meadows of New Jersey, the Marsh Hawk is common and finds plenty of food. A boatman's dog had killed eight rats in the course of a morning but left them to rot. The Marsh Hawk would have consumed the entire carcass.

In the prairie regions of the United States and Canada the Marsh Hawk is abundant. It there feeds largely upon gophers and similar mammals. Occasionally the Marsh Hawk feeds upon birds but these lapses may be excused on account of the good done in the destruction of rodents.

The Marsh Hawk is found over the entire United States and a large part of Canada.

\section{THE OSPREYS}

The Ospreys are next to the Eagles in size. They are nearly cosmopolitan. In the New World they are found in both North and South America. They feed exclusively upon fish. As they cannot dive, the fish they catch are those found in shallow water or near the surface.

\section{American Osprey}

General description. Length, 2 feet; spread of wings, $4 \frac{1}{2}$ to $5 \frac{1}{2}$ feet. Upper parts dark brown; head and under parts white; a dark band on side of head.

The Osprey's feet, with their rough, spiny projections, long and well-curved claws, are perfect fish-traps. As the bird is large 
and powerful its prey seldom escapes. Ospreys plunge after their prey and often do so from quite a height. The fish is carried head first with one talon in front of the other. The bird can probably control its prey in this manner better than in any other.

Ospreys build enormous nests of sticks in the tops of trees. On Gardiner's Island off the eastern end of Long Island, they build their nests upon the ground. Purple Grackles frequently build their nests in crevices in the Ospreys' nests.

The Osprey is generally protected by law in the United States and Canada. Fishermen often complain that this bird destroys too many fish. Most of the fish caught by Ospreys are those of small commercial value. How about the fishermen who dump a whole cargo overboard because they cannot get the price they want? Which is more wasteful?

The Osprey's chief natural enemy is the Bald Eagle which robs it of its catch. The Eagle pursues the Osprey and forces it to drop its hard-earned meal. With a clever swoop the raider catches the fish as it falls and makes off with it.

Except in the prairie regions the Osprey breeds locally and irregularly over the entire United States and Canada north to the tree limit. It is abundant along many parts of the Atlantic Coast. It is never found far from large bodies of water.

\section{THE CARACARAS}

The Caracaras are vulture-like Hawks found chiefly in Central and South America. They have long unfeathered legs. The feathers on the crown are elongated sufficiently to form a crest which is raised or lowered at will. The Caracaras are essentially carrionfeeders. "Their flight is strong, rapid, and direct, and bears no resemblance to that of a vulture." (Chapman.)

\section{Audubon's Caracara}

General description. Length, 25 inches. Adults: Throat, neck all around, front part of back, and breast, dull whitish barred with black; tail dull white with numerous bars of blackish, the terminal 
one being a broad band; crown and rest of plumage blackish. The young are more brown, the darker markings on the body longitudinal streaks, not transverse bars.

Audubon's Caracara is a very grotesque looking bird. They are very quarrelsome among themselves. Though usually carrionfeeders, they often rob Pelicans, forcing them to disgorge fish in their pouches.

Audubon's Caracara is found in northern Lower California, Arizona, Texas, and Florida south through Mexico and Central America.

\section{THE FALCONS}

The Falcons are long-winged Hawks noted for their strength and swiftness. They fly with rapid wing-beats and very little sailing. They capture their prey by sudden swoops. They drop like a bullet, striking with powerful talons as they do so.

With the exception of the little Sparrow Hawk, Falcons are very destructive to birds. Fortunately the Sparrow Hawk is the ontv one that is common.

\section{Prairie Falcon}

General description. Length, male 18 inches; female, 20 inches. Color above, brownish-ash; below, white, spotted.

The Prairie Falcon is a bird of the open prairies, and sagebrush deserts. It resorts to cliffs in which to rear its young. It flies very much like the Duck Hawk and covers a large area in its search for birds and rodents. It takes heavy toll from ground squirrels. In the vicinity of grain elevators on the edge of prairie towns, it will feed upon the domestic pigeons attracted by spilled grain.

The Prairie Falcon is found in the Great Plains, and from southern British Columbia, southern Alberta, and southeastern Saskatchewan to southern Lower California and southern Mexico.

\section{Duck Hawk}

General description. Length, male, 18 inches; female, 19 inches. Color above, bluish-ash; below, yellowish, barred; a black 
streak extends back from the gape forming a "mustache." The young are brown above.

Our Duck Hawk is the American representative of the European bird, the noble Peregrine of Falconry. Duck Hawks are nowhere common and are found amongst the crags of mountainous regions along rivers. A few pairs nest upon the Palisades and the Highlands of the Hudson.

This swift, daring bird makes regular excursions into New York City to prey upon the domestic pigeons. A few of the too abundant pigeons can easily be spared for a rare bird like the Duck Hawk. Meadowlarks and Flickers are also prominent among its victims. It also plays havoc with Ducks and Shore-birds. The Duck Hawk does not habitually feed upon rodents, its diet being almost exclusively birds.

Peale's Falcon is the form inhabiting the Pacific Coast region from the Aleutian Islands to Oregon. It is duskier than the bird found over the rest of the continent.

\section{Pigeon Hawk}

General description. Length, male, 11 inches; female, 13 inches. Color above dark brown; below, whitish streaked with brown. The adult male in full plumage is purplish-ash above.

The Pigeon Hawk may be called a small edition of the Duck Hawk, which it closely resembles in color and actions. It is widely distributed but nowhere common in the United States. It feeds mostly upon birds. All Pigeon Hawks which I have seen perched have been eating birds. I mostly see Pigeon Hawks migrating along the Atlantic Coast.

The Black Pigeon Hawk or Black Merlin and Western Pigeon Hawk are the forms found along the north-west coast region from California to Sitka, Alaska.

Richardson's Merlin is found in the interior of western North America; it breeds in the region of the Great Plains. It averages lighter in coloration than the Pigeon Hawk.

\section{Sparrow Hawk}

General description. Length, 11 inches. Color above, cin- 
namon-rufous; below, pale rusty and whitish. The male has bluish wings. The wings of the female are nearly the same color as the back.

The Sparrow Hawk is the smallest and most sociable of our Hawks. It often nests in hollows of old orchard trees near farm houses and in trees along roadsides. A pair even nested under the eaves of the roof of the American Museum of Natural History in New York City. It nests regularly in various parts of the city.

On account of its small size the Sparrow Hawk does little damage. It feed upon birds chiefly when it can get nothing else. In the summer it destroys countless grasshoppers, crickets, caterpillars, beetles, etc. At other times it feeds upon meadow mice and house mice.

The Sparrow Hawk is found practically over all of North America east of the Rockies. It is very abundant in the central and prairie sections of the United States. I have found it especially so in Illinois and Indiana.

In western North America we have the Desert Sparrow Hawk. This is larger and paler than the ordinary Sparrow Hawk. There are other differences. I found this race quite common in the city of Portland, Ore. In Florida there is a smaller race.

There is a lot of individual variation in the plumage of Sparrow Hawks-the markings around the head, color, etc.

The habit of hovering in the air while watching for prey is a characteristic by which the Sparrow Hawk is easily identified. No other small Hawk has this habit.

\section{THE OWLS}

Owls are nocturnal Birds of Prey. Like the other raptoral birds they capture their prey with their feet and if not too large swallow it whole. The undigested parts are disgorged in the form of a pellet.

The plumage of Owls is very soft and downy. This allows them to fly noiselessly. 


\section{Barn Owl}

General description. Length, 18 inches; spread of wings, 44 inches. Color, whitish tawny, speckled with black. The color varies considerably. Some birds are deep buffy, while others are mostly white. The face is white, with an area of dark red-brown in front of and surrounding the eye; the facial rim is ochraceous buff.

In old barns, ruins, hollow trees, or sand banks-all these places are agreeable to the Barn Owl in which to build its home. My acquaintance with the Barn Owl was made in the ruins of an old mansion which had been destroyed by fire. The chimney had remained standing. Projecting from this chimney were two iron rods. It was upon one or the other of these rods that the Owl would perch for awhile at dusk before setting out to forage.

The Barn Owl is a very beneficial bird in the destruction of harmful rodents. Examination of some pellets disgorged by a pair of these birds proved the major part of their food to be meadow mice and house mice. The Barn Owl is always hungry and rids the country of countless mice. When there are young to be fed of course the toll among the mice is yet greater.

The Barn Owl differs from all the other Owls in having the face somewhat heart-shaped instead of circular. The lower apex is very prominent.

The Barn Owl occurs over the greater part of the United States and Mexico. It breeds north to Long Island, New Jersey, Pennsylvania, western New York, northern Indiana, northern Illinois, southern Nebraska, Colorado, and northern California. It occurs more or less irregularly further northward.

\section{Screech Owl}

General description. Length, 10 inches; spread of wings, 22 inches. Dichromatic; in gray phase, brownish-gray dappled; in red phase, pattern the same but color chestnut-red. Ear-tufts large and conspicuous; toes scantily feathered toward their tips.

This little Owl is perfectly at home about human habitations. It will nest in natural hollows in trees, in bird boxes or even in 
buildings. However, its nests are not prize-winners for cleanliness. A pair of these Owls will use the same nest until driven away or until the death of one of the birds. The Screech Owl apparently mates for life.

Once in coming home from a hike with a group of Scouts we discovered a Screech Owl perched upon a telegraph wire along a much-travelled highway. It eventually flew to some trees.

The name "screech" is not appropriate as the cry of this bird is more of a wailing than anything else. This wailing cry is apt to cause shivers to run up and down the spine of one hearing it for the first time.

On account of its small size the Screech Owl does very little damage. Its food consists of mice and insects. With the exception of the Burrowing Owl it feeds more extensively upon insects than any other of our Owls. It only occasionally feeds upon small birds.

The two color phases of this species are unusual among Owls. Each of a pair may be either color. The young of a dichromatic pair may be all one color. A pair of the same color may have young of the opposite color or of both colors.

There are 15 different geographical races or sub-species of Screech Owls listed. Many of them are restricted in the area they inhabit. The differences of the various forms are beyond the scope of this pamphlet. Some form of Screech Owl is found in practically every part of the United States and most of Canada.

\section{Flammulated Screech Owl}

Differs from preceding species in the toes entirely naked, the ear-tufts short (almost rudimentary), the upper parts grayish (cinnamon-brown in the red phase), finely mottled and marked with hlackish, the facial circle, bright cinnamon to deep brown.

This species ranges from southern British Columbia, eastern Washington, and Idaho, to western Texas, New Mexico, Arizona, and in the higher mountains of California south through Mexico to the highlands of Guatemala. 


\section{Great Horned Owl}

General description. Length, 24 inches; spread of wings, 60 inches. Color, above, sooty-brown or dusky, mottled with grayishwhite; below, whitish, barred with dark; a conspicuous, crescentic area of immaculate white across foreneck. Ear-tufts very conspicuous, about 2 inches in length; toes fully feathered.

Large, strong and ferocious, the Great Horned Owl is the demon of the family. It will attack, kill and eat any creature which it can subdue. Even the skunk is upon its menu. Partridges and rabbits are favorite morsels. When once it tastes domestic poultry it will make constant raids upon the barnyard. However, it is only when farms are near woodlands that this occurs. In the dense forests where this Owl is mostly found it is upon the wild creatures that it exacts its toll.

My acquaintance with the Great Horned Owl was made in Central Park, New York City. It was in March when the trees were still bare of leaves. One of these birds was high up in one of the tall trees. Surrounding him were a flock of Purple Grackles and a gray squirrel all making a racket. The Owl paid no attention to his tormentors. A few days later he was shot by the keeper of the duck pond and-irony of fate-in his claws was the carcass of a hugh rat, partly devoured.

The hemlock forest in Bronx Park is often visited by this Owl. There probably most of its food consists of squirrels and rats. A pine woods in northern New Jersey, recently destroyed, was another place where this and the Barred Owl were regularly found.

Crows take special delight in tormenting this Owl. Whenever they discover one they attack en masse only ceasing when something else attracts their attention or darkness falls. In the latter case the tables may be turned as the Great Horned Owl regularly feeds upon Crows.

There are many geographical races and much individual variation. The Arctic Horned Owl may be almost pure white with little buff showing anywhere, and the black pattern very much reduced in prominence. This race is found in the northwestern parts of Canada. The other extreme is the Dusky Horned Owl, found 
from the interior of Alaska south along the coast to south-central California, and in the Rocky Mountains to Arizona and New Mexico. Some race or other of the Great Horned Owl is found in practically every part of the wooded sections of the United States and Canada.

The Great Horned Owl is probably the earliest nesting of all our birds. It may begin nesting the first week of February or probably the end of January in the south. The female may be brooding under a mantle of snow. The young are often hatched before the snow has disappeared.

\section{Snowy Owl}

General description. Length, 24 inches; spread of wings, 60 inches. Color, white with dark spots. Ear-tufts almost or quite lacking; feet densely covered with hair-like feathers hiding the black claws. Young birds are dusky brown or deep sooty-grayish.

This large handsome Owl is a bird of the northland, where it breeds, and the long days in summer make it chiefly diurnal. It is a bird of the open, frequenting such places. as the frozen mashes and tundras.

On account of its size; strength and swiftness, it captures and feeds upon ducks, ptarmigan, grouse and even such a good sized animal as the Arctic hare. It is also fond of fish either alive or dead. In its migrations it is quite destructive to game birds, but less so than the Great Horned Owl.

The Snowy Owl's winter migrations are variable. Many years may pass without a single specimen being reported in New York State. Suddenly there will be veritable hordes coming down. Unfortunately few of the birds return to the north. Its large size and light color make it a shining target and it is slaughtered everywhere. Some people appear to think that no creature that wears feathers or fur should be allowed to live.

The Snowy Owl inhabits the northern part of the northern hemisphere; in North America it breeds from far within the Arctic Circle southward to northern Ungava, central Keewaitn, central 
Mackenzie and northern British Columbia; in winter southward to more northern United States, irregularly, but sometimes numerously, to Virginia, Illinois, Kansas, Colorado and mouth of Columbia River.

\section{American Hawk Owl}

General description. Length, 17 inches; spread of wings, 34 inches. Color above, dark brown, speckled with white; below, white, barred with brown. No ear-tufts; facial disk poorly developed, making the face hawk-like; tail, long and rounded; feet heavily feathered.

The Hawk Owl is a bird of the north. It is hawk-like in both appearance and actions. It hunts by day and has the habit of perching upon a dead stub, or in plain sight at the top of a tree, watching for its prey with hawk-like alertness. However, its flight is typically owl-like in its noiselessness.

Being a bird of the north, the Hawk Owl cannot very well be taken into consideration as to its being beneficial to agriculture.

The American Hawk Owl is practically restricted to Canada. It only occasionally visits the United States and then rarely as far as Missouri, Indiana, Pennsylvania or New Jersey.

\section{Pygmy Owl}

General description. Length, 7 inches; spread of wings, 15 inches. Color above, grayish-brown spotted with light buff; under parts white, streaked with dark; tail dark brown, barred with white. No ear-tufts.

This little Owl differs from the others in its flight. Its wings make a distinct whistling sound, whereas the flight of other Owls is silent. Its flight is also rather jerky. It hunts in the daytime.

The Pygmy Owl kills and eats birds its own size, as well as rodents. Small birds will make a big fuss when they discover one of these Owls in a pine tree or other dense foliage.

The Pygmy Owl is found in western North America from south-eastern Alaska, interior British Columbia, south to Guate- 
mala, and east to eastern Montana, Colorado, and New Mexico. There are several varieties differing in minor details. Some are more reddish than grayish.

\section{Elf Owl}

General description. Length, 6 inches; spread of wings, 15 inches. Upper parts brown flecked with buff; line over eye white; tail barred with white spots; under parts reddish spotted with white. No ear-tufts.

This is the smallest Owl. The regular place in which to find this bird is among growths of cactus. It nests in holes made by Woodpeckers.

The food consists largely of ants, beetles and grasshoppers. It is a constant night hunter seldom feeding upon birds.

The Elf Owl is found in southern California, southern Arizona, southern New Mexico and the lower Rio Grande Valley in Texas.

\section{Burrowing Owl}

General description. Length, 9-11 inches; spread. of wings, 24 inches. Color above, brown, heavily speckled or dotted with white; under parts white, heavily spotted or barred with brown; white line over the eye; white collar is concealed unless bird straightens up. Head relatively small; legs long.

This funny little Owl is at home in the prairie regions, making its home in the holes of prairie dogs, badgers, etc. Sometimes when the earth is soft this Owl may dig its own hole.

Although the Burrowing Owl makes use of deserted holes, it has been known to share the same hole with prairie dogs and also with the prairie rattlesnake. The Owls and snakes probably feed upon the young of each other and both feed upon the young rodents.

The Burrowing Owl feeds upon anything it can catch. It has been known to catch and eat birds as large as the Nighthawk.

The Western Burrowing Owl is found on the Pacific Coast of the United States east to Minnesota, western Iowa and Louisiana, 
and from the British Columbia and Manitoba, south to Panama. The Florida Burrowing Owl inhabits the prairie region of central and southern Florida.

\section{Barred Owl}

General description. Length, 20 inches; spread of wings, 44 inches. Plumage, brown, barred with whitish. No ear-tufts or "horns."

This rather large Owl is an inhabitant of the woodland and is one of the most inoffensive of all. He rarely molests poultry or wild birds for that matter. The larger part of his food is mice. This Owl also feeds upon frogs, lizards, crawfish, spiders and various insects.

The Barred Owl was a regular resident in the pine woods in northern New Jersey which has since been destroyed. The ground in these woods was littered with pellets disgorged by the Owls. Practically all contained the remains of mice. Once I found Blue Jay feathers and once those of a Junco. These were the only remains of birds found in this locality.

The hooting of the Barred Owl is loud and sonorous. This loud hooting may be continued all through the night. This has caused the bird also to be called "Hoot" Owl.

Blue Jays and Crows take great delight in teasing this Owl. Many a time in the pine wood mentioned I have heard a flock of Crows making a racket and suddenly seen a Barred Owl leave a tree and be immediately chased by the Crows. The proximity of a human being was probably the cause of the Crows giving up the chase.

The Barred Owl breeds from northern Ontario, Manitoba, Saskatchewan, southern Quebec and Newfoundland south to Arkansas, Tennessee, Kentucky, northern Georgia, and northwestern South Carolina and west to western Wyoming, central Montana, and eastern Colorado.

The Florida Barred Owl is found in the South Atlantic and 
Gulf States from central North Carolina to eastern Texas, north to northern Alabama and Arkansas. Its coloration is similar to the type species but its toes are wholly naked except a strip on the outer side of the middle toe.

The Texas Barred Owl is found only in south-central Texas. Its toes are like those of the Florida Barred Owl, but the color is paler; the white is more conspicuous; the bill and feet are much larger.

\section{Spotted Owl}

General description. Length, 18-19 inches; spread of wings, 45 inches. Color above, brown with numerous white spots; facial disk yellowish-brown, faintly ringed with dark brown; under parts, yellowish brown, breast spotted with white, flanks with broad white spots, giving the effect of barring.

The Spotted Owl is the western representative of the Barred Owl which it resembles in general appearance. It is a trifle smaller. The notes are also similar to those of the eastern bird. It is reported as being tame and gentle. This latter is a trait often characteristic of western wild life.

There are three races of this bird. The California Spotted Owl is found in the mountains of southern California and northern Lower California north along the western flank of the Sierra Nevada. The Northern Spotted Owl ranges from northern California to southern British Columbia. The Mexican Spotted Owl is found in Colorado, New Mexico, and western Texas through the mountains of Arizona to the mountains of central Mexico.

\section{Great Gray Owl}

General description. Length, 30 inches; spread of wings, 60 inches. Plumage grayish-brown, darker and waved above, lighter and streaked below. No ear-tufts.

This is the largest American Owl but its soft, fluffy plumage makes it appear much larger than it really is. It is a bird of the 
north where it is forced to do much of its hunting by daylight. It is very rare in the United States and little is known about its habits.

The Great Gray Owl breeds in the Hudsonian and upper Canadian Zones from tree limit in north-central Alaska and northwestern Mackenzie south to the central Sierre Nevada of California, northern Idaho, northern Montana and Ontario. In winter it wanders southward irregularly but never far.

\section{Long-Eared Owl}

General description. Length, 16 inches; spread of wings, 40 inches. Color above, a mottling of blackish-brown and grayishwhite; below, white and buff, barred spotted with brown. Eartufts conspicuous.

The Long-eared Owl usually spends the day perched in an evergreen tree or a tree that is densely leaved. In spite of its size it is often hard to see. When discovered it has a habit of stretching itself and raising its ear-tufts. In this position it looks more like a stump than a bird. This is one of the few Owls which go around in flocks.

The place where I have seen this species most often is in the Moravian Cemetery, Staten Island, New York City. There is an extensive grove of pines, hemlock and spruce which furnishes shelter for the Owls. As many as a dozen have been flushed from the trees. A way to make them fly is to bang upon the tree-trunks with a stick. They will all then come out with a rush. It is comical to walk entirely around a small tree in which a Longeared Owl is perched. The bird will follow one's movements and apparently twist its head entirely around. Of course this is not done. The head is turned as far as it will go in one direction and then immediately turned to the other side. The movement is so rapid that the human eye can hardly follow it.

The Long-eared Owl is a famous mouser and does a tremendous amount of good in this respect. Its presence should be encouraged. 
The Long-eared Owl is found over practically all of temperate North America. In the winter it extends its range to central Mexico. Its northern limit is Newfoundland and practically across the continent to southern Alaska.

\section{Short-Eared Owl}

General description. Length, 14 inches; spread of wings, 42 inches. Color, a variegation of yellowish-white and dark brown. Ear-tufts, rudimentary and inconspicuous.

The Short-eared Owl is a bird of the bogs and marshes. When hunting it skims low over the ground and then appears to be larger than it really is. The long wings give it this aspect. The Short-eared differs in habits from most other Owls in that it does much of its hunting in the daytime. A favorable time to see it is toward dusk or on a cloudy day.

During migrations Short-eared Owls gather in flocks. I remember flushing eight from a small area at Long Beach, L. I., N. Y. Long Beach was at that time a favorable place for Shorteared Owls but this locality has been ruined with a concrete highway and other "improvements." In fact practically all of the hunting grounds of this bird in the vicinity of New York City have been destroyed.

Fully 75 per cent of the food of this Owl consists of mice. Small birds such as the Sparrows which inhabit the marshes are also sometimes taken. On account of its being a bird of the open and flying in daylight this Owl is often shot by thoughtless hunters.

The Short-eared Owl is found over the whole of North and South America; breeding locally, nearly throughout its range except in the more southern parts of the eastern United States, where not ascertained to breed, south of Massachusetts, northern Ohio, northern Indiana, Missouri, Kansas and Colorado; winters practically throughout the United States; it is also found in much of the eastern hemisphere. 


\section{Richardson's Owl}

General description. Length, 11 inches; spread of wings; 24 inches. Color above, brown, spotted with white; below, white, spotted with dark. No ear-tufts.

Richardson's Owl is not only nocturnal in its habits, but apparently is made completely blind by the sunlight. Many specimens have been captured alive by persons walking up and taking them in their hands. I once heard of one being caught that way in Connecticut. The Esquimos in Alaska have given it the name "Blind Owl."

This Owl is too small to do much damage. "It feeds chiefly upon mice, but occasionally the remains of small birds have been found in the stomach.

Richardson's Owl breeds in the Hudsonian and upper Canadian zones from the limit of trees in central Alaska and northern Yukon and Mackenzie south to northern British Columbia, northern Alberta, Manitoba, Nova Scotia, and the Magdalen Islands. In winter it ranges south to southern Canada and southwestern British Columbia. It is casual in the northern United States, rare in the east.

\section{Saw-Whet Owl}

General description. Length, 8 inches; spread of wings, 18 inches. Color above, brown spotted with white; facial disc whitish with a blackish area around and in front of the eye, border of the disc dark brown spotted with white. No ear-tufts.

In winter this dainty little Owl is liable to be found in most unlooked for places. The first one I ever saw was in a tree in one of the streets of Brooklyn. Another was not more than four feet from the ground, in a pine tree. It had a red-backed mouse in its claws. There were two Boy Scouts with me and the Owl took turns between watching us and pecking at the mouse.

Once some Manhattan Scouts found a Saw-whet Owl in Central Park. They picked it up off of its perch and carried it to the 
American Museum of Natural History to verify their identification. They then carried it back to the park and replaced it upon its original perch where it remained.

This little Owl feeds chiefly upon mice and is therefore one of the most beneficial species. Also on account of its small size it often falls a victim to some of the large Owls.

The Saw-whet Owl breeds from southern Alaska, central British Columbia, Alberta, Manitoba, Quebec, New Brunswick, and Nova Scotia south to the Sierra Nevada of California, central Arizona, New Mexico, Oklahoma, and the mountains of Mexico; also in southern Nebraska, northern Indiana, northern Illinois, and in the mountains of Pennsylvania and Maryland. Winters south to southern California, Louisiana, Virginia, and casually to the Carolinas and Georgia.

A variety, the Queen Charlotte Owl, is found only on the Queen Charlotte Islands, British Columbia.

From the foregoing it will be seen that the beneficial Hawks are the larger, slower flying species. They are all more often found in the open, where they beat their way to and fro searching for their prey. The Marsh Hawk, Buzzards and Rough-legs are all in this group.

The smaller, swift-flying Hawks are the ones which are destructive to bird-life. The Goshawk, Cooper's, Sharp-shinned, Duck and Pigeon Hawks are all in this group. The little Sparrow Hawk is in between. It is too small to tackle any rodents other than mice and occasionally feeds upon small birds. Its food, however, is comprised chiefly of grasshoppers and insects. 
